\title{
Kaizen Promotion in Ethiopia: A Role of the Government and Change of Mindset of People
}

\author{
Kimiaki Jin
}

\section{INTRODUCTION}

\subsection{Background}

The Ethiopian government began piloting Kaizen in 2009 and scaling it up in 2011 in Ethiopia. Following its satisfiable results of Kaizen promotion from 2011 until 2014, the government incorporated Kaizen dissemination into the country's five-year development plan (2015-2020). In the meantime, several international media ${ }^{1}$ have covered Kaizen promotion in Ethiopia as a part of stories related to its good economic performance, epitomized by a decade of double-digit growth of the gross domestic product (GDP) from mid-2000s till early 2010s. Many African countries and regional organizations, such as the New Partnership for Africa's

Kimiaki Jin works for the Research Institute and the Private Sector Development Group, Industrial Development and Public Policy Department, Japan International Cooperation Agency (JICA), Japan.

K. Jin $(\bowtie)$

Research Program Division, JICA Research Institute, Japan International Cooperation Agency (JICA), Tokyo, Japan e-mail: Jin.Kimiaki@jica.go.jp

(C) The Author(s) 2020

A. Hosono et al. (eds.), Workers, Managers, Productivity, https://doi.org/10.1007/978-981-15-0364-1_5 
Development (NEPAD), have also shown a strong interest in adopting Kaizen. Nowadays, Kaizen in Africa is attracting considerable interest from policymakers, practitioners, researchers and students.

Several key factors may have contributed to its rapid progress in Ethiopia. One factor in the supply side of Kaizen services may be the proactive role of the government guided by the then prime minister Meles Zenawi, as this chapter illustrates. However, the question is whether any method will generate good results when a government shows strong commitment. Also, assuming that this is not, by itself, a sufficient condition, we would need to consider what other key factors may have contributed to the promotion of Kaizen in Ethiopia. A factor which we would focus on in this chapter is how Kaizen creates changes on the ground as the nature of the approach itself brings benefits to its practitioners.

\subsection{Framework of the Analysis}

In order to deepen our understanding of the factors behind Kaizen promotion, this research focuses on the intrinsic character of Kaizen and analyzes how its application has contributed to the development of various capacities of practitioners within companies and organizations. To analyze the benefits for these practitioners, the "framework of capacity assessment" developed by UNDP (2008) and JICA (2008) is used. According to capacity assessment methods, capacity can be stratified into individual capacity, organizational capacity, and enabling environments.

It is also categorized into technical capacity in the form of techniques and particular knowledge and core capacity (capacity to address core issues in individual and organizational levels), which utilizes technical capacity to independently solve issues, including will, attitude, and leadership. Hosono et al. (2011) define core capacity as generic and crosscutting competencies and the ability to commit and engage, to identify needs and key issues, to plan, budget, execute, and monitor actions, and to acquire knowledge and skills. They point out that the challenge is how to enhance effectively such crosscutting core capacity.

In considering a framework of Kaizen, its tools and methods have dimensions focusing on issues related to technical/scientific aspects which can be calculated and controlled, and dimensions of human aspects of workers/management which cannot be calculated and controlled in the exact meaning (Jin 2018). Based on these categorizations, capacities can be divided, as shown in Table 5.1, for use in the research framework for 
Table 5.1 Categorization of capacities

\begin{tabular}{|c|c|c|}
\hline & $\begin{array}{l}\text { Technical Aspects } \\
\text { (measurable) }\end{array}$ & $\begin{array}{c}\text { Human Aspects } \\
\text { (difficult to measure) }\end{array}$ \\
\hline $\begin{array}{l}\text { Enabling } \\
\text { Environment }\end{array}$ & $\begin{array}{l}\text { Economic growth, } \\
\text { regulatory system of business, } \\
\text { and foreign exchange }\end{array}$ & $\begin{array}{l}\text { Social norms, } \\
\text { religious and cultural aspects, } \\
\text { and mutual aid in a society }\end{array}$ \\
\hline $\begin{array}{l}\text { Organizational } \\
\text { Capacity }\end{array}$ & $\begin{array}{l}\text { Organizational structures, } \\
\text { machinery \& equipment, } \\
\text { information technology, } \\
\text { and resource allocation }\end{array}$ & $\begin{array}{l}\text { Decision making systems, } \\
\text { labor management systems, } \\
\text { incentive system, } \\
\text { (and corporate culture) }\end{array}$ \\
\hline $\begin{array}{l}\text { Individual } \\
\text { Capacity }\end{array}$ & $\begin{array}{c}\text { Technical capacity } \\
\text { (sector specific technologies, } \\
\text { skills and } \\
\text { knowledge management) }\end{array}$ & $\begin{array}{c}\text { Core capacity } \\
\text { (discipline, will, motivation, } \\
\text { learning attitude, } \\
\text { leadership of individuals) }\end{array}$ \\
\hline
\end{tabular}

Source: Author, based on UNDP (2008) and JICA (2008)

further arguments. Core capacity, such as motivation, self-discipline and communication skills, is also characterized as a "non-cognitive" skill (Joshi 2014). And it has common elements with "socio-behavioral skills" such as aptitude for teamwork and empathy pointed out by the World Bank (2019).

One hypothesis of this research is that Kaizen may be accepted by the companies and organizations in Ethiopia because it addresses development of not only their technical capacity but also the core capacity of workers and management, which can be distinguished by using the framework of capacity assessment. Improvement of core capacity provides a means of stimulating the participation of workers, motivating learning and acceptance of changes for streamlining production systems in the company.

\subsection{Structure and Methods of Analysis}

In Sect. 2, this chapter illustrates how the government of Ethiopia has been promoting Kaizen in the country as a case study. The section first provides an overview of the government's strategies and actions to 
promote reforms since the current ruling party took power in 1991. This helps to provide a historical context regarding the role of Kaizen. It also explains, through focusing on developmental policy, why the government has shown strong commitment to implementing Kaizen across the country. The section further reports inputs and outputs of Kaizen promotion based on the government data.

In Sect. 3, the chapter describes changes resulting from the introduction of Kaizen into the companies/organizations where the staff became its actual practitioners. Major parts of this section depend on interviews and a questionnaire survey conducted with the practitioners. The structured survey questions, with a range of possible choices, were as follows: (1) what kind of Kaizen tools are being applied in the company, (2) what kind of positive changes are being created, and (3) do you want to proceed to a higher level of Kaizen. Because Kaizen covers a very broad range of tools and technologies at different levels, as shown in Table 5.2 (Sugimoto 2018), it is important to identify the tools applied for the assessment of capacity development as outcomes. Questions also covered challenges to the sustainability of the activities. Key questions made and results of the survey are found in the Appendix.

The chapter finally discusses possible implications in Sect. 4 followed by concluding remarks in the Sect. 5 .

Table 5.2 Comprehensive features of Kaizen tools and technologies

\begin{tabular}{|c|c|c|c|c|c|c|}
\hline \multirow{2}{*}{\multicolumn{2}{|c|}{ Levels }} & \multicolumn{5}{|c|}{ Target* of technology } \\
\hline & & Quality & Productivity & Cost & Delivery & Others \\
\hline \multicolumn{2}{|c|}{$\begin{array}{l}\text { Advanced } \\
\text { Kaizen }\end{array}$} & $\begin{array}{l}\text { Taguchi method } \\
\text { Experimental design } \\
\text { Quality function } \\
\text { deployment } \\
\text { Reliability } \\
\end{array}$ & 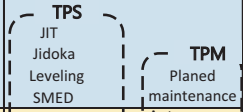 & $\begin{array}{l}\text { Economic engineering } \\
\text { NPV } \\
\text { Target costing } \\
\text { Activity-based costing }\end{array}$ & $\begin{array}{l}\text { Decoupling point } \\
\text { APS }\end{array}$ & \\
\hline \multicolumn{2}{|c|}{$\begin{array}{l}\text { Intermediate } \\
\text { Kaizen }\end{array}$} & 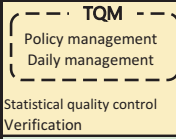 & $\begin{cases}\text { Kanban } & \text { Autonomous } \\
\text { Poka-yoke } & \text { I maintenance } \\
\text { Cell production } & \text { OEE } \\
\text { TOC (Theory of constraint) } \\
\text { Multiple activity analysis }\end{cases}$ & $\begin{array}{l}\text { Value engineering } \\
\text { Value analysis } \\
\text { Standard costing }\end{array}$ & $\begin{array}{l}\text { Cell production } \\
\text { MRP } \\
\text { Pull production }\end{array}$ & $\begin{array}{l}\text { Value stream mapping } \\
\text { SWOT analysis } \\
\text { Five forces analysis } \\
\text { Value chain analysis } \\
\text { Ergonomics } \\
\end{array}$ \\
\hline \multirow[t]{2}{*}{$\begin{array}{l}\text { Basic } \\
\text { Kaizen }\end{array}$} & $\begin{array}{l}\text { Fundamental } \\
\text { technology }\end{array}$ & $\begin{array}{l}\text { Control chart } \\
\text { Process capability index } \\
\text { OC process chart }\end{array}$ & $\begin{array}{cc}\text { I } & \text { Process analysis } \\
\text { I } & \text { Motion study, Time study } \\
\text { I } & \text { Work analysis } \\
\text { Work sampling }\end{array}$ & $\begin{array}{l}\text { Direct costing } \\
\text { Cost accounting }\end{array}$ & & \\
\hline & $\begin{array}{l}\text { Common** } \\
\text { Kaizen tech. }\end{array}$ & $\begin{array}{l}\cdot 5 \mathrm{~S}, \cdot 7 \mathrm{QC} \text { tools, } \bullet \text { New } 7 \\
\cdot \text { Visualization, } \bullet \text { Muda eli }\end{array}$ & $\begin{array}{l}\mathrm{QQC} \text { tools, } \cdot \text { Why-why analysis, } \cdot \mathrm{Br} \\
\text { imination, } \cdot \mathrm{QC} \text { circle, } \cdot \text { Cross functi }\end{array}$ & $\begin{array}{l}\text { ain storming, } \bullet \text { TWI } \\
\text { ional team, } \cdot \text { Suggestion }\end{array}$ & ystem & \\
\hline \multicolumn{2}{|c|}{ Meta Kaizen technology*** } & \multicolumn{5}{|c|}{$\begin{array}{l}\bullet \mathrm{PDCA}, \bullet \mathrm{SDCA}, \bullet \mathrm{QC} \text { Story, } \bullet \text { Problem solving procedure, } \bullet \text { Task achieving procedure } \\
\bigcirc \text { Project management }\end{array}$} \\
\hline
\end{tabular}

Source: Sugimoto (2018) 


\section{Policy and Actions Taken by the Government OF ETHIOPIA}

\subsection{Reforms Apart from Kaizen in Ethiopia}

Ethiopian production systems have generally been characterized by low levels of productivity and inconstant quality of products compared with industrialized countries. The decision-making process in organizations is generally portrayed by strong top-down processes, but its implementation on the ground is often disorganized and not very efficient. Chanie (2001) argues that this is partly due to the low capacity of the civil service to cope with prevailing social, political and economic difficulties, as well as management innovations.

Cognizant of these facts, since the current ruling party assumed power in 1991 after defeating the former socialist government, reforms have been introduced across political, economic and social spheres. From 1996 until 2009, the Public Sector Capacity Building Program (PSCAP) was initiated to bring about comprehensive civil service reform, focusing on (1) expenditure management and control, (2) human resource management, (3) enhancement of the top management system, (4) improved service delivery and quality of service, and (5) ethics and judicial reform. The outcome of PSCAP was satisfactory (World Bank Group 2013).

Several other reform approaches were also attempted. Business Process Re-engineering (BPR) was implemented in parallel with PSCAP, commencing in 2004, because service delivery by public institutes was very slow, costly and non-responsive to the needs of customers (Gebrehiwot 2010). The concept of BPR emphasizes the fundamental reconsideration and radical redesign of organizational processes to realize a drastic increase in performance, particularly by eliminating the work that does not add any value for customers.

However, some evaluation reports on BPR (Debela 2009; Setegn et al. 2013; Kebede and Abetwe 2017) concluded that BPR had failed to bring about drastic change and contributed only limited improvement in the Ethiopian civil service delivery. In addition, there was dissatisfaction among workers at the organizations because BPR puts greater emphasis on processes that benefit the organizations than it does on human resources development. Absence of alternative employment or safety net schemes to absorb laid-off manpower resulting from the change process gave rise to negative perceptions of the process that severely hindered and eventually undermined the sustainability of BPR. 
Furthermore, as part of the ongoing civil service reform that the government is undertaking, a balanced score card (BSC) has been under implementation since 2011. It is an approach that integrates strategic planning, implementing and measuring the performance of all actors involved in the realization of the goals and objectives of the country (MoCS 2013).

The Ethiopian government has a strong policy orientation toward the developmental state, as Meles Zenawi argues in his paper (Zenawi 2012). He defines the "developmental state" as the single-minded pursuit of accelerated development with the strong superiority of the public sector over the private sector. Along with this policy direction, the government led by Prime Minister Meles Zenawi and his successor Prime Minister Hailemariam Desalegn undertook 14 capacity-building programs to accelerate industrial development including Technical and Vocational Education and Training (TVET), Engineering Capacity Building Program (ECBP), Textile and Garments Capacity Building Program (TG-CBP), Private Sector Development Program (PSDP) and Information Communication Technology Development Program (ICT-DP).

Outcomes of the capacity-building programs included the establishment of eight institutes, such as the Textile Industry Development Institute (TIDI), Leather Industry Development Institute (LIDI), and Metal Industry Development Institute (MIDI). These institutes provide support for the development of specific technical skills, which is technical capacity, for private companies in priority subindustries. Furthermore, the government has been simultaneously investing heavily in the development of key infrastructures such as transportation, power supply and industrial parks, and applying different industrial development tools to attract foreign direct investment as Oqubay (2015) describes.

Since 1991, the economy of Ethiopia had fluctuated, attributing to the character of a rain-fed agrarian economy. However, from 2004 the economy has been in a high growth trajectory and performed double-digit growth for more than a decade. ${ }^{2}$ This growth was sustained by a balanced growth of agriculture, industry and services ${ }^{3}$ until 2013. From 2014, growth of the industry has become higher than that of other sectors, which has triggered economic transformation. ${ }^{4}$ On the other hand, growth of the manufacturing industry is not significantly high and its share in GDP remains at 4.3 percent as of 2016, which is not higher than its average between 2003 and 2016 (4.7 percent). Therefore, the country does not yet reach a stage wherein growth of the manufacturing industry leads 
to the country's economic growth. It means that the impact of Kaizen at the macro level in the manufacturing industry is not yet visible. In addition, causality between Kaizen and economic growth in the macro level is always difficult to analyze due to the complex multifactorial influences affecting both.

\subsection{Kaizen Promotion by the Government}

The introduction of the Japanese Kaizen approach into Ethiopia was initiated by then Prime Minister Meles Zenawi in 2008, who directly requested assistance related to Kaizen from the Japanese government. Zenawi referred to a book chapter written by Kikuchi (2008) about a quality and productivity improvement project in Tunisia supported by the Japan International Cooperation Agency (JICA), and explained to the mission members ${ }^{5}$ sent by JICA headquarters that he wanted to develop a Kaizen approach, as JICA had done in Tunisia, among other tools to promote industrial development. He promised the mission that the government would assign five to ten staff members to form a new unit that will work with Japanese experts on Kaizen.

His intentions regarding technology transfer are clearly detailed in his article on the developmental state (Zenawi 2012). He argues that the investment in human resources development to create continuous upgrading of standards is more effective in mastering existing technologies during the catch-up process for developing countries than investment in research infrastructure for innovation. Meles deliberately chose the Japanese Kaizen as a relatively low-cost approach for investing in human resources. In fact, Kaizen promotes the gradual and continuous improvement of existing technologies by utilizing the know-how of floor workers without the need for large-scale capital investment. Strong guidance by Meles was one of the reasons why the government has maintained a firm commitment to Kaizen.

In 2009 Kaizen was introduced to the Ethiopian manufacturing sector through the first project titled the "Study on Quality and Productivity Improvement (KAIZEN) in the Federal Democratic Republic of Ethiopia" to test its applicability in the Ethiopian context. After verifying its effectiveness, the Kaizen unit with ten staff was expanded to become the Ethiopia Kaizen Institute (EKI) in 2011, an independent organization with a technical staff of 60 people who were trained to be consultants. This rapid scale-up of the implementing body of Kaizen created the 
capacity in the government to apply Kaizen across a wider range of targets. Several sector-specific development institutes, such as TIDI, LIDI and MIDI, were put in place to facilitate human resources development for industrialization. EKI is communicating closely with these sector-specific institutes and trying to mainstream Kaizen training for future industrial extension agents.

In mid-2014, the government formed the National Kaizen Council chaired by then Prime Minister Hailemariam Desalegn. The Council is the highest decision-making body for the national Kaizen movement and meets quarterly to deliberate on plans and endorse new directions. During the first extraordinary meeting that the Council had in September 2014, the Council set the month of September (the first month Meskerem in the Ethiopian calendar, commencing on September 11 or 12, depending on the leap year) as Kaizen month in order to promote the concept as a national movement. The government also started creating regional Kaizen institutes in the major regional states to further strengthen the dissemination of Kaizen across the country.

EKI, the main promoter of Kaizen activities in Ethiopia, provided training to 68,954 trainees and established 9658 Kaizen Promotion Teams (KPTs; a customized version of the Quality Control Circle (QCC) ${ }^{7}$ in Ethiopia) in 473 target institutes from 2012/2013 to 2016/2017 (Mekonen 2018). It provides training and consultations to large and medium enterprises directly and training to micro and small enterprises through Technical and Vocational Education and Training (TVET) as Suzuki and Sakamaki report in Chap. 7 of this book. EKI received its recurrent and capital budget from the government, which amounted to 119.3 million birrs ${ }^{8}$ since its establishment in 2011 until 2016/17. ${ }^{9}$ EKI estimated that the benefits of Kaizen implementation between 2011 and 2016 reached 2169.5 million birrs, equivalent to US\$105 million (Mekonen 2018). Mekonen vividly illustrates the details about the strategy, activities and challenges of EKI regarding Kaizen promotion.

One remarkable point is that while EKI implemented the Kaizen training within a framework of the project agreement between JICA and the government, EKI also started providing basic Kaizen consultations—soon after mastering basic skills - to the large-scale parastatal companies located outside Addis Ababa, who were not targets of the project. Such activities of EKI initially created tension between EKI members and JICA experts because the JICA team complained about the potential negative effects on the quality of Kaizen training implemented only by EKI staff, as well as delays in their project activities. 
However, as a symbolic episode, it shows the strong ownership of and expectations by the Ethiopian participants related to Kaizen promotion in the country - a point that is now highly appreciated by JICA. ${ }^{10}$ The management of EKI also became more strategic and capable of handling requests from high-level government officials regarding the application of Kaizen to parastatal factories, while at the same time working to maintain project activities supported by JICA.

Based on these achievements, the government of Ethiopia incorporated a proposal for Kaizen mainstreaming into its five-year national development plan, the Growth and Transformation Plan II (GTP II), in order to scale up Kaizen promotion across the country (NPC 2016).

On the other hand, in 2015 the government changed the supervising ministry of EKI from the Ministry of Industry to the Ministry of Public Service and Human Resource Development, which represents its policy expansion to applying Kaizen, not only to the development of industry but also to the public sector and broader human resources development. Local Kaizen institutes were also established in Addis Ababa and Dire Dawa municipalities and the Oromia Regional Government promoted Kaizen in local institutes and companies.

From 2013, EKI started sharing its experiences of Kaizen promotion with neighboring countries, receiving study missions from Sudan, the Democratic Republic of Congo, Tanzania and Zambia (JICA et al. 2018b). NEPAD also sent a mission in 2017 to learn about the Ethiopian model of Kaizen promotion in order to prepare a position paper on the Africa Kaizen Initiative, which aims to accelerate industrialization, economic transformation and creation of decent work in Africa between 2017 and 2026. Therefore, other countries and organizations in Africa are expecting to learn something from the case of Ethiopia.

\section{Kaizen Practices and Outcomes in Companies/ Organizations}

Regarding the outcomes of Kaizen, there are several cases studied. Desta (2014) reported on the case of the Kaizen approach in the Methara Sugar Factory, which is located $200 \mathrm{~km}$ southeast of Addis Ababa. He cites data from the sugar company, indicating that the outputs of the sugarcane plantation and sugar production increased by 35 percent and 37 percent, respectively, as a result of Kaizen techniques introduced in 2013. These improvements came after a serious decline in sugar output from 120,000 tons to 80,000 tons in the four years between 2009 and 2012 . 
Desta and Gebrehana (2015) further analyze the case of the Wonji Sugar Factory and conclude that the achievements of the factory thus far can be considered quite laudable, particularly those made by the factory workers and sugarcane producers, while the achievements by the employees in service and administrative work lagged behind.

\subsection{Outline of the Survey}

In order to articulate how the practitioners in the companies understand the outcomes of Kaizen techniques, a questionnaire survey and interviews were conducted. The target group of the survey is 60 companies/organizations with accessible contact e-mail addresses ${ }^{11}$ that EKI had provided to the author out of 631 companies trained as of July 2017. As multiple respondents ${ }^{12}$ from one company were accepted, the 38 responses were collected from 33 companies/organizations.

Out of 33, 19 are large-scale companies/organizations, 9 are mediumscale ones, $\mathrm{l}$ is a small company and 4 are unknown ones. Regarding industry, eight are in textile, four are in construction, four are in metal, three are in food/beverage, three are in leather, five are in other manufacturing sector and six are in the service sector. In terms of location, 18 are in Addis Ababa and its suburb. Six are in Mekele, eight are in other rural towns and one's location is unknown.

These companies evaluated their Kaizen activities quite positively. Therefore, in order to avoid selection bias, the chapter doesn't judge if Kaizen is well accepted or not in Ethiopia. It can be said that the survey represents the opinions of a sample that is sympathetic to Kaizen, and who can provide an explanation of why Kaizen has been accepted by them. However, for the judgment on acceptance of Kaizen in Ethiopia, it needs to observe further proliferation of Kaizen in the country.

\subsection{Outcomes of Kaizen in Companies/Organizations}

Figure 5.1, composed of two bar graphs, compares two interlinked features - one is tools applied by Kaizen activities on the left side and another is changes created in the workplace as results of Kaizen activities on the right side.

Figure 5.1 (1) shows the percentage of the respondents who answer the question on what kinds of Kaizen tools are applied in the respondents' own workplace (multiple-choice). As Kaizen consists of many different 

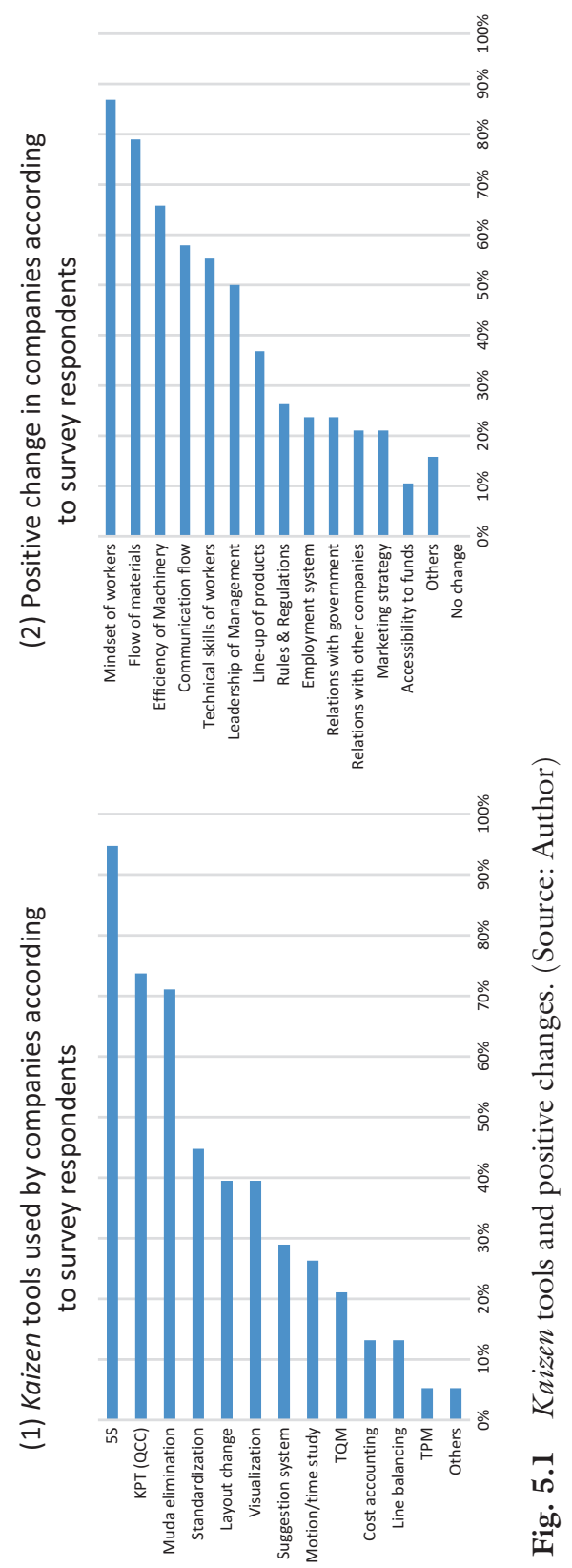
tools and methods categorized in different levels, the replies vary. However, in more than half of the workplaces, the tools applied are 5S, KPT (QCC), and muda elimination, which are basic and common Kaizen tools that can target several issues in the production process (see Table 5.2).

$5 \mathrm{~S}$ (sort, set in order, shine, standardize and sustain) is a housekeeping tool to implement the bottom-up type participatory process of sorting out and disposing unnecessary items at the workplace, deciding where to put necessary items, and keeping the workplace clean and in good condition. KPT (Kaizen Promotion Team) is a customized version of the Quality Control Circle (QCC). Muda elimination is an activity to identify any step which does not produce added value and minimize them from the production process. These activities do not require high-level technical skills but participation of people in all levels of management, supervisors and workers to apply simple rules and make small efforts.

Figure 5.1 (2) shows responses to a question on what kinds of positive change have resulted from the introduction of Kaizen. The bar graph indicates the percentage of respondents who select each choice (multiplechoice) although the selection criterion is subjective based on working experiences of each respondent who is a leader of Kaizen activities in each workplace. The change selected by more than half of respondents, ranked in order according to the most often chosen, are (1) mindset of workers, (2) flow of materials, (3) efficiency of machinery, (4) communication flow, (5) technical skills of workers and (6) leadership by management. "Mindset of workers" was chosen by 87 percent of the respondents as a feature that changed in the workplace. Changes in flow of materials and efficiency of machinery can be direct results of $5 \mathrm{~S}$ and muda elimination. Changes in mindset, communication flow, leadership as well as technical skills of workers can be indirect results of all 5S, KPTs and muda elimination.

Figure 5.2 shows the percentage of respondents who select choices (multiple-choice) against the question of what kind of changes in mindset have been observed. This question is made in order to clarify what mindset change is. Teamwork, communication and learning attitudes are the most commonly chosen three followed by self-confidence and proactiveness, while punctuality and obedience are relatively low. Although these changes are not precisely measurable and often ignored in many quantitative studies on the impact of Kaizen, most of respondents as leaders of Kaizen activities in the workplace observed such features as changes in mindset of workers based on their own experience. They are categorized as core capacity in the framework of capacity assessment. 


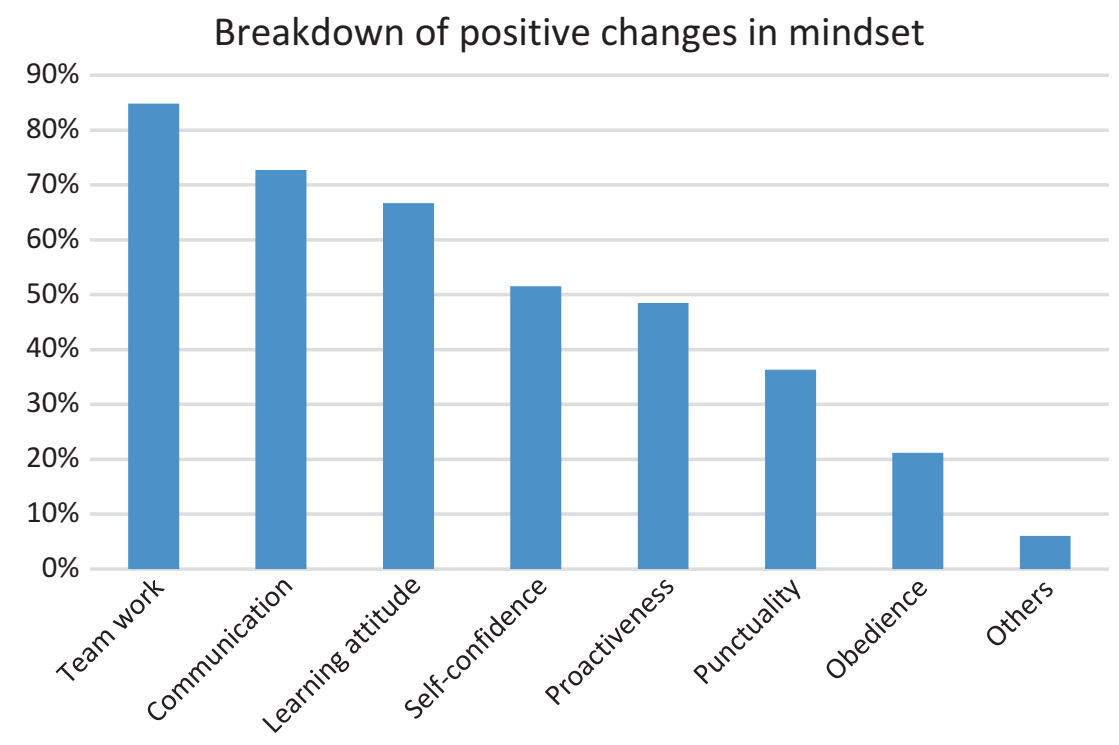

Fig. 5.2 Mindset changes. (Source: Author)

Regarding the responses to a question on profits created by the introduction of Kaizen, half of the respondents ${ }^{13}$ selected that profits have increased a lot, while the other half chose that profits have increased only a little. The impacts on profit do not appear to depend on the length of Kaizen practice among this limited number of the sample. For the next step, all of them want to participate in higher level Kaizen training and a half of them are willing to participate even if they have to pay a training fee (current Kaizen training is provided by EKI free of charge).

Other results obtained from the survey indicate that, out of a total of 38 responses, only one respondent says that there has been a negative impact resulting from the introduction of Kaizen, referring to the time lost due to weekly meetings. For the other 36 respondents (excluding one non-answer), there has been no negative impacts caused by the implementation of Kaizen in their workplace.

Regarding challenges to sustainability, from the multiple-choice answers, the low participation of workers was chosen by one-third of respondents, with turnover of staff and limited training opportunities also selected by one-third of the respondents. For countermeasures, more than 
four-fifths say that the commitment of management is important while three-fourths chose continuous training, followed by giving awards for Kaizen practice chosen by two-thirds.

\subsection{Spillover Effects}

Three-fifths of the respondents ${ }^{14}$ replied that they had observed spillover effects of Kaizen outside of their workplace, particularly at the residence of workers. One interesting case was observed in 2014 at the Wonji Sugar Factory, which is a large-scale sugar plantation and factory complex. The workers live in the settlements near the plantation fields and have shared their Kaizen experiences with the community members, modifying them to improve health and hygiene activities.

The Wonji Shoa Sugar Factory was established in the early 1960s, and it currently has over 3000 permanent and contract employees dwelling in a camp within the vicinity of the factory. Within one and half years of the introduction of Kaizen in 2012, impressive results were obtained at the health facilities that were also targets of Kaizen activities. Some of the rapid achievements observed include (1) an increase in customer satisfaction, (2) a decrease in the rate of malingerers visiting the health post, (3) a decrease in the incidence of health leave and referral system abuse, (4) improved resource management, (5) changes in the attitude of the physicians in that they started to perceive themselves as an integral part of the sugar production process and (6) removal of two top killer diseasesmalaria and bilharzia (schistosomiasis) -which were among the top-ten health risks affecting the workforce.

Gradually, the frontline workers utilizing $5 S$ who were impressed by the participatory nature of Kaizen started to take Kaizen practices with themselves from the factory floor to their homes and implemented it themselves, without management support. Recognizing the positive actions that individual workers had shown, the management was very encouraged and showed its willingness to support further implementation of Kaizen practices within workers' families in their settlements. Workers' family members and neighboring sugarcane growers outside of the plantations have been organized into women's and men's "development armies" and their activities are integrated into health extension services. These groups gather for weekly meetings every Friday, discuss their problems and search for robust solutions. Moreover, they perform weekly cleaning 
in their respective villages, drain swamp areas, burn dry waste, and tackle local crime through community policing.

These activities in the communities are a spillover effect of the introduction of Kaizen into factories and health facilities, especially through the development of the core capacity of the people, as discussed later. And they are similar to community development activities in the post-war reconstruction period in Japan called livelihood improvement or SeikatsuKaizen (JICA 2011).

However, business at the Wonji Shoa Sugar Factory has been stagnating during the last several years because of financial constraints, logistic issues and security conditions caused by political instability in the country. ${ }^{15}$ Although the workshop of the factory has been maintained in good condition due to $5 \mathrm{~S}$ practices and the hospital workers are continuing KPT activities as of early 2018, the sustainability of Kaizen has become a critical issue. The turnover of staff who have been trained as Kaizen leaders and the lack of upgraded information and training programs have affected the motivation of workers, although the company keeps providing basic training programs for newly recruited staff. Some workers have started feeling that KPT is creating additional work for them, and the momentum within the groups has not been as high as before.

\section{Discussion}

\subsection{The Role of the Government}

As the past actions of the government of Ethiopia described in Sect. 2 show, promotion of Kaizen in the country was initiated and guided by the government, particularly by former Prime Ministers, Meles Zenawi and Hailemariam Desalegn. The government established EKI, a promotion organization, and allocated the necessary resources. The management of EKI was capable and strategic in effectively utilizing resources mobilized from Japan, a fact that was also highly appreciated by the JICA staff. EKI and high-ranking government officials organized a big campaign to raise public awareness. The Kaizen promotion system has been further strengthened by the establishment of regional Kaizen institutes. These actions resulted in the change of mindset of workers in addition to improving the flow of materials and efficiency of machinery described in Sect. 3. 
This pattern of Kaizen promotion is similar to the one introduced to Singapore, led by then Prime Minister Lee Kuan Yew and supported by JICA, in the 1980s (NPB and JICA 1990). The case is a typical example of government-led Kaizen dissemination argued by Homma in Chap. 6 of this book. And an important point of the case in Ethiopia is that the approach taken by the government is neither top-down enforcement nor uniform application of Kaizen activities to companies/organizations. It creates good practices first by applying Kaizen to selected companies to be a model for other wider target groups and encourages them to adopt similar practices.

Even prior to the Kaizen promotion, the government of Ethiopia was undertaking a series of efforts to improve the capacity of the public sector starting from the mid-1990s. This was followed by efforts to support the private sector from the mid-2000s, backed up by a deliberate policy study on the developmental state by Zenawi. Therefore, it is obvious that the proactive role of the government as a promoter of Kaizen is one of the key factors to create the results.

The institutional setting of EKI is summarized in Table 5.3 (1) as capacity development of a Kaizen promotion organization, which is a supply side system in Ethiopia. As a promoter of Kaizen, EKI has introduced incentive systems, a better salary system than other public organizations and the opportunity of a master's degree education to promising staff, as important organizational capacity (Mekonen 2018). EKI keeps providing training to its staff through classroom training and in-company training, which develop the technical skills of Kaizen as well as the mindset of staff as individual capacity.

\subsection{Responses by the People in the Workplace}

Although monetary benefit is important, there are other benefits that are not in monetary terms but appreciated by the practitioners. It is because half of the survey respondents have selected that monetary benefit is only a little but show willingness to learn more about Kaizen. The practitioners appreciated changes created by Kaizen.

Out of six major positive changes created by Kaizen, flow of materials, efficiency of machinery, and technical skills of workers are categorized as technical aspects of capacity. Mindset of workers, communication flow and leadership of management are understood as human aspects of the capacity under the framework of capacity assessment (see Table 5.3 (2)). 
Table 5.3 Issues improved by creation of EKI and introduction of Kaizen in companies

(1) Institutional setting of EKI

\begin{tabular}{|c|c|c|}
\hline & \multicolumn{2}{|c|}{ Kaizen Promoters } \\
\hline & $\begin{array}{c}\text { Technical } \\
\text { Aspects }\end{array}$ & $\begin{array}{l}\text { Human } \\
\text { Aspects }\end{array}$ \\
\hline $\begin{array}{l}\text { Enabling } \\
\text { Environment }\end{array}$ & $\begin{array}{l}\text { Developmental sta } \\
\text { sector reforms by }\end{array}$ & $\begin{array}{l}\text { e policy and public } \\
\text { the government }\end{array}$ \\
\hline $\begin{array}{c}\text { Organizational } \\
\text { Capacity }\end{array}$ & $\begin{array}{l}\text { Establishment of } \\
\text { EKI, allocation of } \\
\text { budget, and } \\
\text { preparation of work } \\
\text { plan with } \\
\text { quantitative targets }\end{array}$ & $\begin{array}{l}\text { Strategic leadership, } \\
\text { better salary and } \\
\text { education system as } \\
\text { incentives for the } \\
\text { staff }\end{array}$ \\
\hline $\begin{array}{l}\text { Individual } \\
\text { Capacity }\end{array}$ & $\begin{array}{l}\text { Technical } \\
\text { knowledge and } \\
\text { methodologies to be } \\
\text { Kaizen consultants }\end{array}$ & $\begin{array}{l}\text { Development of } \\
\text { Kaizen mindset } \\
\text { among staffs as } \\
\text { consultants }\end{array}$ \\
\hline
\end{tabular}

(2) Positive change in companies

\begin{tabular}{|c|c|}
\hline \multicolumn{2}{|c|}{ Kaizen Practitioners } \\
\hline $\begin{array}{l}\text { Technical } \\
\text { Aspects }\end{array}$ & $\begin{array}{l}\text { Human } \\
\text { Aspects }\end{array}$ \\
\hline \multicolumn{2}{|c|}{$\begin{array}{l}\text { Economic growth and } \\
\text { atmosphere of social change }\end{array}$} \\
\hline $\begin{array}{l}\text { Better flow of } \\
\text { materials and } \\
\text { efficiency of } \\
\text { machinery (by } 5 \mathrm{~S} \\
\text { and muda } \\
\text { elimination) }\end{array}$ & $\begin{array}{c}\text { Better } \\
\text { communication and } \\
\text { leadership in the } \\
\text { company (by } \\
\text { implementation of } \\
5 \mathrm{~S}, \text { muda } \\
\text { elimination and KPT } \\
\text { activities) }\end{array}$ \\
\hline $\begin{array}{l}\text { Improved technical } \\
\text { skills of workers }\end{array}$ & $\begin{array}{l}\text { Changed mindset of } \\
\text { workers and } \\
\text { managements (in } \\
\text { terms of team work, } \\
\text { communication and } \\
\text { learning attitude) }\end{array}$ \\
\hline
\end{tabular}

Source: Kimiaki Jin

Changes in flow of materials and efficiency of machinery are typical outputs of Kaizen activities and technical skills of workers may be developed in connection with them.

\subsubsection{Development of Core Capacities Through Kaizen}

It can be said that observed change of mindset of workers (teamwork, communication, learning attitude) and leadership of management are results of collective activities of 5S, QCC and muda elimination.

As explained in Sect. 3, 5S involves bottom-up-type participatory activities of housekeeping, which can foster capacity of people to work in a group with good communication and to keep rules and regulations that they have set. Although it is a simple and basic tool, it provides foundation for application of advanced tools of Kaizen like Total Quality Management (TQM), Toyota Production System (TPS) and Total Productive Maintenance (TPM) (Sugimoto 2018). There are JICA cooperation projects for improvement of hospital management that introduce 5S-CQI (continuous quality improvement)-TQM in Sri Lanka, Bangladesh, 
Tanzania and other African countries (Take et al. 2015; Kanamori et al. 2016).

QCC involves small group activities in which workers are encouraged to contribute to improvement of daily work. QCC creates opportunity to utilize knowledge of frontline workers who are conversant with the conditions of the workplace. Through the efforts of improving their own work, workers can also develop better learning attitudes so that they can positively accept and manage various changes in workplace.

The Ethiopian government recognized the broad applicability of Kaizen to other sectors. Therefore, the government changed the supervising ministry of EKI from the Ministry of Industry to the Ministry of Public Service and Human Resource Development in 2015 and then to the Civil Service Commission under the Prime Minister's Office in 2018.

The capacities that provide foundation for utilizing other technical methodologies and influence on attitude and leadership as crosscutting competencies are the one we call core capacity. Mindset change of people through Kaizen application can be said to be a process of core capacity development. This core capacity, once developed, is referred to as a Kaizen mindset and is an important part of the development of society beyond traditional systems. And the development of core capacity is appreciated by people in Ethiopian context.

As the spillover effects observed among practitioners of Kaizen demonstrate, capacities developed by Kaizen have broad applicability. And the Kaizen mindset of people strengthened by better communication, teamwork and learning processes in the workplace may create stronger coherence of the workforce in the company, hence higher collective productivity. That is one of the reasons why Kaizen is accepted by many practitioners even if monetary profits are not necessarily high.

\subsubsection{Job Security of Workers}

Another minor but important aspect to be noted is that no one is really affected negatively by Kaizen. People do not want to be treated like a disposable workforce by employers through a reform process. This point has critical importance in societies with limited dynamism in labor markets, such as Ethiopia, because it is difficult to find new job opportunities once people are dismissed. Workers don't appreciate any reform activities that affect their job security negatively, which is the other side of the coin of productivity improvement.

It can be learned from the case of BPR that aims to reorganize existing systems effectively and dismantle the non-value-adding activities and pro- 
cesses. However, workers did not support BPR because of its technical and engineering approach and inadequate attention to human aspects (Debela 2009; Kebede and Abetwe 2017). Kaizen attracts more support from workers and creates a mindset to participate in change because it takes a balanced and human-centered approach between the technical and human aspects shown in Table 5.3.

A JICA report on the Kaizen project phase I in Ethiopia (JICA and GDMC 2011) briefly discusses two domains of dissemination of Kaizen activities in its conclusion chapter-namely institutionalization and human factors. For the human factors, the report states as follows:

It is the men and women in the organization who actually work and execute what the organizations are supposed to deliver. An organization should manage its human resources in alignment with the organization activity goals and, in so doing, should strive to create a motivated workforce. Workplace Kaizen, in part, helps to improve employee motivation.

Sugimoto (2018) explains how Kaizen management responds once surplus manpower is generated through labor-saving activities. He says that it is the worst case if management makes the surplus workers redundant in order of their inferior work-related competence. A better way of labor saving is to pick out excellent workers from the production floor and to assign them to more creative jobs. This is one of the essences of Kaizen.

\subsubsection{Sustainability of Kaizen Activities}

Sustainability is another issue that requires careful examination. Most of the respondents selected one or more challenges related to sustainability, such as the limited participation of workers, limited training opportunities and high turnover of staff. Wonji Sugar Factory was once a good performer of Kaizen, but its officers in charge are now reporting challenges and remarking on the importance of continuous support from EKI for advanced training to maintain momentum. As countermeasures, the commitment of management and continuous training for workers are selected by the respondents.

These results imply that Kaizen is easy to start-even with limited investments-because of its significant focus on human aspects such as mindset change. However, in order to sustain the activities, continuous stimulation of the workers and tangible commitment from the management are essential. 
In other words, Kaizen may be more sustainable if the Kaizen mindset is incorporated into corporate culture shared among the management and labor. In this context, the JICA Kaizen Handbook (2018a) states that the core value of Kaizen is placed in creating the attitude shared among all members of an organization who consistently pursue advanced levels of quality and productivity. Shared value among a certain size of a group of people has strong influence on the mindset of its members.

\section{Concluding Remarks}

Strong ownership and proactive actions-including the establishment of promotion organizations, resource allocation and public campaigns-are measures that the government can work on. However, these efforts may depend on how seriously the government believes in the effectiveness of Kaizen among other policy options. In the case of Ethiopia, the government has a clear vision that Kaizen needs to be promoted by the public sector instead of leaving it to the market mechanism.

If government doesn't have such developmental policy, the requirement of strong ownership may create a chicken-and-egg argument because the realization of tangible success in a short period requires a strong commitment from the government and strong commitment requires tangible evidence for success. However, visionary leaders (in terms of economic growth of a nation), ${ }^{16}$ such as Lee Kuan Yew and Meles Zenawi, had their own confidence and guided their respective national movements.

Kaizen is effective in changing the mindset of people, particularly in strengthening motivation toward teamwork, communication and learning attitudes, which are categorized as core capacity. Hence, Kaizen can be one of the answers to the question on how to enhance core capacity effectively pointed out by Hosono et al. (2011). And, it may contribute to the development of socio-behavioral skills of workers that are increasingly important in the changing nature of work according to the World Bank (2019).

In many African countries, there may be a large potential to improve quality and productivity through the development of core capacity as observed in Ethiopia. These changes don't require high technical skills and large capital investment but do require collective efforts among people who can think and act by themselves with their own intrinsic motivation. We have to encourage and capacitate people by using Kaizen because, at the end of the day, all development we seek is for people. 


\section{APPENDIX}

Table 5.4 Results of selected questions in the questionnaire survey

\begin{tabular}{|c|c|c|c|}
\hline No. & Question & Choices & Result \\
\hline \multirow[t]{6}{*}{ C-20 } & When did your company introduce Kaizen? & Before 2013 & 7 \\
\hline & & $2013 / 14$ & 10 \\
\hline & & $2014 / 15$ & 5 \\
\hline & & $2015 / 16$ & 3 \\
\hline & & $2016 / 17$ and after & 13 \\
\hline & & No introduction & 1 \\
\hline \multirow[t]{13}{*}{ C-21 } & What kind of Kaizen tools did you apply & $5 \mathrm{~S}$ & 36 \\
\hline & & Muda elimination & 27 \\
\hline & & Standardization & 17 \\
\hline & & Visualization & 15 \\
\hline & & Suggestion system & 11 \\
\hline & & $\mathrm{KPT}$ & 28 \\
\hline & & Line balancing & 5 \\
\hline & & Layout change & 15 \\
\hline & & Motion/time study & 10 \\
\hline & & Cost accounting & 5 \\
\hline & & TQM & 8 \\
\hline & & TPM & 2 \\
\hline & & Others & 2 \\
\hline \multirow[t]{15}{*}{ C-22 } & What kind of positive changes, if any, have & No change & 0 \\
\hline & & Efficiency of machineries & 25 \\
\hline & & Material flow & 30 \\
\hline & & Line-up of products & 14 \\
\hline & & Accessibility to funds & 4 \\
\hline & & Marketing strategy & 8 \\
\hline & & $\begin{array}{l}\text { Relation with } \\
\text { government }\end{array}$ & 9 \\
\hline & & $\begin{array}{l}\text { Relation with other } \\
\text { companies }\end{array}$ & 8 \\
\hline & & Rules and regulations & 10 \\
\hline & & Employment system & 9 \\
\hline & & $\begin{array}{l}\text { Leadership of } \\
\text { management }\end{array}$ & 19 \\
\hline & & Communication flow & 22 \\
\hline & & Technical skill & 21 \\
\hline & & Mindset of workers & 33 \\
\hline & & Others & 6 \\
\hline
\end{tabular}


Table 5.4 (continued)

\begin{tabular}{|c|c|c|c|}
\hline No. & Question & Choices & Result \\
\hline \multirow[t]{8}{*}{$\mathrm{C}-23$} & If you chose "mindset of workers" in the above & Proactiveness $^{\mathrm{b}}$ & 17 \\
\hline & & Self-confidence & 18 \\
\hline & & Learning attitude ${ }^{\mathrm{b}}$ & 23 \\
\hline & & Punctuality & 13 \\
\hline & & Obedience & 8 \\
\hline & & Communication & 25 \\
\hline & & Team work & 29 \\
\hline & & Others & 2 \\
\hline \multirow[t]{2}{*}{$\mathrm{C}-24$} & $\begin{array}{l}\text { Is there any negative change induced by } \\
\text { Kaizen? }\end{array}$ & No negative change & 36 \\
\hline & & Yes & 1 \\
\hline \multirow[t]{4}{*}{$\mathrm{C}-25$} & Do these changes bring better profit in & No & 0 \\
\hline & & Yes, but only a little & 16 \\
\hline & & Yes, a lot & 18 \\
\hline & & Don't know & 1 \\
\hline \multirow[t]{10}{*}{$\mathrm{C}-31$} & $\begin{array}{l}\text { What are key challenges in sustaining Kaizen } \\
\text { activities in your company (multiple)? }\end{array}$ & None & 3 \\
\hline & & Participation of workers & 14 \\
\hline & & Difficulty of method & 5 \\
\hline & & Finance & 5 \\
\hline & & Training opportunity & 12 \\
\hline & & Business environment & 4 \\
\hline & & Turnover of staff & 12 \\
\hline & & $\begin{array}{l}\text { Low commitment by } \\
\text { management }\end{array}$ & 9 \\
\hline & & Security & 0 \\
\hline & & Others & 4 \\
\hline \multirow[t]{9}{*}{ C-32 } & What kind of measures are effective in & Nothing & 0 \\
\hline & & $\mathrm{KPT}$ & 23 \\
\hline & & Awarding & 25 \\
\hline & & $\begin{array}{l}\text { Commitment by } \\
\text { management }\end{array}$ & 33 \\
\hline & & Continuous training & 29 \\
\hline & & Government campaign & 3 \\
\hline & & Economic growth & 5 \\
\hline & & $\begin{array}{l}\text { Combination with other } \\
\text { business support }\end{array}$ & 7 \\
\hline & & Others & 4 \\
\hline
\end{tabular}


Table 5.4 (continued)

\begin{tabular}{lllc}
\hline No. Question & Choices & Result \\
\hline C-34 & $\begin{array}{l}\text { Are you willing to participate in a higher level } \\
\text { of Kaizen training? }\end{array}$ & No & 0 \\
& & Yes, if free & 21 \\
C-35 & Do you know any spillover effect of Kaizen & No & 21 \\
& activities outside of your company? & Yes charged & 14 \\
& & Business partner & 21 \\
& & Neighboring & 9 \\
& & community & 9 \\
& & Staff residence & 14 \\
C-37 Have you created or experienced any & Others & 2 \\
innovations in your company? & No & 12 \\
C-38 If yes, did Kaizen contribute to the innovation? & No & 24 \\
& & Yes & 5 \\
\hline
\end{tabular}

${ }^{a}$ The total number of responses to C-20 is 39 because one respondent selected two choices. The author interpreted that the company introduced Kaizen twice

${ }^{\text {b}}$ Regarding mindset, motivation and creativity are reworded to proactiveness and learning attitude, respectively, since others find it difficult to recognize motivation and creativity

\section{Notes}

1. For example, see https://www.bbc.com/news/business-26542963, https://www.bbc.com/news/av/business-31551228/ethiopian-businesses-adopt-japanese-kaizen-philosophy and https://allafrica.com/stories/201609261329.html.

2. The average GDP growth rate between 2004 and 2016 was 10.6 percent according to calculation based on the World Development Indicators. GDP per capita in constant 2010 US\$ was 511 dollars in 2016 (WB 2018).

3. Between 2004 and 2014, both agriculture and service sectors maintained more than 40 percent of GDP share, respectively, while share of the industry sector was lower than 15 percent (WB 2018).

4. Share of industry in GDP grew from 11.9 percent in 2013 to 20.3 percent in 2016 (WB 2018).

5. Members of the mission who met Prime Minister Zenawi in December 2008 were Prof. K. Ohno, Prof. I. Ohno, Prof. Hosono, Mr. Kikuchi and the author. 
6. The project was implemented from 2009 to 2011 as phase I, and included pilot activities of Kaizen in 30 companies, verified effectiveness of Kaizen and produced a set of manuals.

7. QCC is a small group at the workplace who discusses about and improves work at the production floor.

8. Equivalent to around US\$5.8 million. The budget covered the whole cost for implementation of JICA project phase II during 2011-2014 (Project on Capacity Building for Dissemination of Quality and Productivity Improvement (KAIZEN)) and a part of the project phase III during 2015-2020 (Project on Capacity Development for KAIZEN Implementation for Quality and Productivity Improvement and Competitiveness Enhancement) as well as EKI's own promotion activities of Kaizen.

9. Project cost borne by JICA from JFY2011 to JFY2016 is 870.3 million yen (equivalent to US\$9.42 million based on OECD Stat exchange rate).

10. JICA President awarded EKI in 2015 for its outstanding performance as a project counterpart.

11. EKI selected companies who have e-mail addresses and can smoothly communicate in English with a good response.

12. Kaizen officers in different departments in a large company were encouraged to respond to the questionnaire. Responses from the same company vary depending on departments due to different timing of Kaizen introduction and the character of independent small group activities in parallel. Hence the response obtained from each department is treated equally as other responses.

13. The respondents exclude three public organizations that don't earn any profit.

14. See C-35 in the Appendix.

15. A series of demonstrations, road blocks and burning down of public offices called Oromo protest that happened during 2015-2018 was one of the political and security problems of the country.

16. There may be different arguments on leaders in terms of democracy and human rights.

\section{REFERENCES}

Chanie, P. 2001. The Challenges of the Civil Service Reform in Ethiopia: Initial Observation. East African Social Science Research Review 17 (1): 79-102.

Debela, T. 2009. Business Process Reengineering in Ethiopian Public Organizations: The Relationship Between Theory and Practice. Journal of Business and Administrative Studies 1 (2): 20-59. 
Desta, A. 2014. The Art of the Kaizen Approach for Sugar Production in Ethiopia: Lessons from the Methara Sugar Factory. International Journal of Operations and Logistics Management 3 (3): 212-221.

Desta, A., and A.A.G. Gebrehana. 2015. Kaizen Management Issues at the Wonji Sugar Factory in Ethiopia: A Comparative Analysis. European Journal of Management 15 (2): 7-26.

Gebrehiwot, B.A. 2010. Comparative Analysis of Some Western versus Japanese Management Techniques in the Context of Ethiopia. http://www.grips.ac.jp/ forum/af-growth/support_ethiopia/document/Berihu_Kaizen\&BPR.pdf.

Hosono, A., S. Honda, M. Sato, and M. Ono. 2011. Inside the Black Box of Capacity Development. In Catalyzing Development, A New Vision for Aid, ed. H. Kharas, K. Makino, and W. Jung. Washington, DC: Brookings Institution Press.

Japan International Cooperation Agency (JICA). 2008. Capacity Assessment Handbook: Project Management for Realizing Capacity Development. Tokyo: JICA Research Institute.

JICA. 2011. Wisdom of the Livelihood Improvement (KAIZEN) in Post-War Japan: Lessons Learnt from the First Developing Country. Tokyo: JICA. http://open_ jicareport.jica.go.jp/810/810/810_000_12066163.html.

JICA, and Global Development \& Management Consultants (GDMC). 2011. The Study on Quality and Productivity Improvement (KAIZEN) in the Federal Democratic Republic of Ethiopia, Final Report. Tokyo: JICA. http://open_ jicareport.jica.go.jp/810/810/810_000_12066163.html

JICA, UNICO International, and Japan Productivity Centre (JPC). 2018a. Kaizen Handbook. Tokyo: JICA. https://www.jica.go.jp/english/news/ field/2018/180625_01.html.

- 2018b. Project Kenkyu Africa Kaizen Shien-ni-kakaru, Hyojun Approach Sakutei Chosa [Study on Standardizing Kaizen Approaches for Further Dissemination and Deployment in Africa]. Tokyo: JICA.

Jin, K. 2018. Role of Kaizen in Japan's Overseas Development Cooperation. In Applying the Kaizen in Africa: A New Avenue for Industrial Development, ed. K. Otsuka, K. Jin, and T. Sonobe. Cham: Palgrave Macmillan.

Joshi, H. 2014. Non-cognitive' Skills: What are They and How Can They Be Measured in the British Cohort Studies? CLS Working Paper 2014/6. Institute of Education, University of London, London.

Kanamori, S., M. Castro, S. Sow, R. Matsuno, A. Cissokho, and M. Jimba. 2016. Impact of the Japanese 5S Management Method on Patients' and Caretakers' Satisfaction: A Quasi-experimental Study in Senegal. Global Health Action 9: 32852. 
Kebede, A., and D. Abetwe. 2017. Implementation of BPR at a Public University in Ethiopia: A Fashion or a Solution? In Management Challenges in Different Types of African Firms, ed. L. Achtenhagen and E. Brundin. Singapore: Springer.

Kikuchi, T. 2008. The Quality and Productivity Improvement Project in Tunisia: A Comparison of Japanese and EU Approaches. In Diversity and Complementarity in Development Aid-East Asian Lessons for African Growth, ed. GRIPS Development Forum. Tokyo: GRIPS.

Mekonen, G.T. 2018. Kaizen as Policy Instrument: The Case of Ethiopia. In Applying the Kaizen in Africa: A New Avenue for Industrial Development, ed. K. Otsuka, K. Jin, and T. Sonobe. Cham: Palgrave Macmillan.

Ministry of Civil Service (MoCS). 2013. In Brief: The Civil Service Reform Program in Ethiopia. Addis Ababa: Ministry of Civil Service.

National Planning Commission (NPC). 2016. Federal Democratic Republic of Ethiopia: Growth and Transformation Plan II (GTP II) (2015/16-2019/20). Vol. I: Main Text. Addis Ababa: NPC.

National Productivity Board (NPB) and Japan International Cooperation Agency (JICA). 1990. Further Fields to Conquer... A PDP Commemorative Publication. Singapore and Tokyo: National Productivity Board and JICA.

Oqubay, A. 2015. Made in Africa, Industrial Policy in Ethiopia. Oxford: Oxford University Press.

Setegn, D., M. Ensernu, and P.K. Moorthy. 2013. Assessing the Effect of Business Process Reengineering on Organizational Performance: A Case Study of Bureau of Finance and Economic Development (BoFED), Oromia Regional State, Ethiopia. Researchers World 4 (1): 115-123.

Sugimoto, S. 2018. Kaizen in Practice. In Applying the Kaizen in Africa: A New Avenue for Industrial Development, ed. K. Otsuka, K. Jin, and T. Sonobe. Cham: Palgrave Macmillan.

Take, N., S. Byakika, H. Tasei, and T. Yoshikawa. 2015. The Effect of 5S-Continuous Quality Improvement-Total Quality Management Approach on Staff Motivation, Patients' Waiting Time and Patient Satisfaction with Services at Hospitals in Uganda. Journal of Public Health in Africa 6: 486.

United Nations Development Programme (UNDP). 2008. Capacity Assessment Practice Note. New York: UNDP.

World Bank (WB). 2018. World Development Indicators. https://data.worldbank.org/products/wdi.

World Bank. 2019. World Development Report 2019: The Changing Nature of Work. Washington, DC: World Bank.

World Bank Group. 2013. Implementation Completion Report (ICR) ReviewPublic Sector Capacity Building Program Support Project (PSCAP). Independent Evaluation Group (IEG). http://lnweb90.worldbank.org/oed/ 
oeddoclib.nsf/DocUNIDViewForJavaSearch/8525682E0068603785257B9 6007187CD? opendocument.

Zenawi, M. 2012. States and Markets: Neoliberal Limitations and the Case for a Developmental State. In Good Growth and Governance in Africa, Rethinking Development Strategies, ed. Akbar Noman, Kwesi Botchwey, Howard Stein, and Joseph E. Stiglitz, 140-174. Oxford: Oxford University Press.

Open Access This chapter is licensed under the terms of the Creative Commons Attribution 4.0 International License (http://creativecommons.org/licenses/ by $/ 4.0 /$ ), which permits use, sharing, adaptation, distribution and reproduction in any medium or format, as long as you give appropriate credit to the original author(s) and the source, provide a link to the Creative Commons licence and indicate if changes were made.

The images or other third party material in this chapter are included in the chapter's Creative Commons licence, unless indicated otherwise in a credit line to the material. If material is not included in the chapter's Creative Commons licence and your intended use is not permitted by statutory regulation or exceeds the permitted use, you will need to obtain permission directly from the copyright holder.

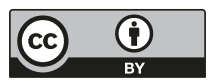

